\title{
Switching Behavior Customers of Sharia Banks in Indonesia
}

\author{
Andi Ainil Mufidah Tanra ${ }^{1}$, Nadhira Afdalia ${ }^{1}$, Latifah Sukmawati Yuniar ${ }^{1, *}$, \\ M. Ikbal Abdullah ${ }^{1}$, Tenripada ${ }^{1}$, Abdul Kahar ${ }^{1}$, Erwan Sastrawan ${ }^{2}$
}

\author{
${ }^{I}$ Department of Accounting, Faculty of Economics and Business, Tadulako University, Palu \\ ${ }^{2}$ Department of Management, Faculty of Economics and Business, Tadulako University, Palu \\ Corresponding Author. Email: latifahsukmawati90@gmail.com
}

\begin{abstract}
The rapid growth of Islamic banks shows great consumer interest in Islamic banks. This research was conducted to analyze the factors that cause consumers to switch from conventional banks to Islamic banks. The population in this study were users of Bank Sharia Mandiri, BNI Sharia, BTN Sharia, and BRI Sharia. Primary data collection through distributing questionnaires with 114 respondents conducted by quota sampling. Data is analyzed by using confirmatory factor analysis. The results showed that the dominant factors that caused consumers to switch from conventional banks to Islamic banks were ethical issues and service quality. Apart from that, there are also factors of price / product and spiritual quality which also trigger consumer movement. These findings indicate that banking companies must be able to identify consumer desires in order to maintain and increase consumer loyalty by continuing to deliver good services. With an increase in service, consumers can feel more comfortable in making transactions.
\end{abstract}

Keywords: Switching Behavior, Islamic Bank, Theory of Planned Behavior

\section{INTRODUCTION}

The development in the banking world is currently increasing rapidly with a wide variety of service products offered, so that consumers have many choices in choosing service products offered by banks. The bank is the safest and most official and legal place for savings and loans. Therefore, consumers do not need to worry about making transactions. However, consumers must also be smart in choosing a bank in accordance with the wishes of the consumers themselves. This is because each bank has its own character and criteria, depending on the consumer in choosing the most suitable bank.

The bank is an intermediary institution, whose role is to accept deposits from customers and lend them to other customers who need funds. In conventional banking, the difference between the amount of interest charged to fund borrowers and the interest paid to depositors of funds is the biggest source of profit. However, there is a different banking system according to Islamic economics which is based on the concept of profit sharing, both profits and losses are borne by consumers and companies. The general principle is that whoever wants to get the results from his savings, must also be willing to take risks for the losses that occur.
The banking system according to Islamic Economics, better known as Islamic Banking, was established to implement Islamic principles in financial institutions. Sharia banking is not only required to generate profit commercially, but is also required to truly display the realization of Islamic values. Sharia banking exists because in conventional banking there are activities that are prohibited by Islamic Sharia, such as receiving and paying interest (usury), financing the production and trading of prohibited goods such as liquor (haram), activities that are very close to gambling (maisir) for certain transactions, namely, foreign exchange dealing, as well as highly and intended speculative transactions (gharar) in investment banking.

The characteristics of the Sharia banking system that operates on the basis of profit-sharing principles provide an alternative banking system that is mutually beneficial for the public and the bank, and emphasizes the aspects of fairness in transactions, ethical investment, prioritizes the values of togetherness and brotherhood in production, and avoids speculative activities in financial transactions. By providing a variety of banking products and services with more varied financial schemes, Islamic banking has become an alternative banking 
system that is credible and can be enjoyed by all groups of people without exception.

The rapid growth of Islamic banks shows great consumer interest in Islamic banks. What causes consumers to switch from conventional banks to Islamic banks? Is this really caused by internal factors of consumers themselves or due to external factors? Is there a devotion factor that causes consumers to switch from conventional banks to Islamic banks? To answer this, it is necessary to conduct a study on the analysis of consumer behavior in switching brands from conventional banking products to Islamic banking in Palu City.

Thus, the Theory of Planned Behavior can assume that perceived behavioral control has motivational implications for behavior. Thus, it is expected that there will be a relationship between perceived behavioral control and behavior. Perceived behavior control can not only influence behavior indirectly through behavior, and can also predict behavior directly.

\section{LITERATURE REVIEW}

Bank of Indonesia provides definition of Islamic Bank is an intermediary institution and financial service provider that works based on ethics and Islamic value systems, especially those that are free from interest (usury), free from unproductively speculative activities such as gambling (maysir), free from ambiguous and dubious (gharar) procedure, upholding justice, and only funds halal business activities.

The consumer movement is a condition in where customers switch from one service provider to another [8]. The Consumer movement is consumer behaviour that reflects a change from a product brand that is commonly consumed to another brand [6]. Meanwhile, brand shifting is a behaviour carried out by consumers for certain reasons, or it is also interpreted as a consumer's vulnerability to switch to another brand [5]. Based on this definition, it can be explained that brand shifting is the time when a customer or a group of customers shift their loyalty from one brand of a particular product to another.

Theory of Planned Behaviour (TPB) is a further development of TRA. [1] adds a construct that is not yet in TRA, namely perceived behavioural control. This construct is added to understand the limitations that individuals have in order to carry out certain behaviours [3]. In other words, whether or not a behaviour is carried out is not only determined by subjective attitudes and norms, but also individual perceptions towards controls that can be carried out based on their belief in these controls (control beliefs).

In the decision-making process of the Muslim community to use Islamic banking products and services as customers, it is influenced by internal Muslim factors, one of which is social factors, including the level of spirituality, price or product, ethical issues and service quality.

\section{EMPIRICAL OVERVIEW}

The price, reputation, responses to service failures, customer satisfaction, service quality, service products, competition, customer commitment and voluntary switching have significant effect on customer switching behaviour [10]. In addition, the cost satisfaction switching and alternative enticement are the predictor variables most commonly used to explain the switching intention of a customer [4]. Costs switching, subjective norms, and interpersonal relationships moderate the relation between switching intentions and their predecessors.

The impact of needs based on behaviour and opportunity, the impact of technology, innovation, demographic changes, image, brand, perception, behaviour, attitudes, loyalty, advertising and other factors that have significant effects that trigger and motivate mobile user behaviour in maintaining their loyalty with existing brands or switching to other brands [2].

Research conducted by [9] entitled Factors Influencing Customer Decisions in Choosing an Islamic Bank shows that partially, product, price and learning have significant positive effect on customer decisions to save at BNI Sharia Bank. While the factors of promotion, location, employees, processes, physical evidence, motivation and perceptions do not have significant effect on the customer's decision to save at BNI Sharia Bank. The determining factors for Muslim societies to choose Islamic banks are religiosity and understanding. Meanwhile, services and facilities do not influence community decisions in the sense that this aspect does not support respondents to become customers or choose Islamic banks [7].

\section{RESEARCH METHODS}

This study is a field study, which is a direct data collection method by distributing questionnaires or draft questions relevant to the Likert scale. The population in this study were users of the savings services at Bank Sharia Mandiri, BNI Sharia, BTN Sharia, and BRI Sharia who switch from conventional banking in Palu City.

The sampling technique used was the quota sampling method, which was carried out randomly. Quota sampling is a sampling technique by chance according to the desired number of respondents. The samples studied are the sample of respondents who domicile in Palu City and have switched from conventional banks to Islamic banks. The number of respondents studied were 114 people. The data analysis method used was factor analysis, namely confirmatory factor analysis.

\section{RESULT}

\section{Confirmatory Factor Analysis}

Factors are variables that have similar concepts. By using factor analysis, these variables will be combined into one factor. Combining variables or summarizing many variables into different factors is the purpose of using factor analysis. This is also intended to avoid the 
possibility of excessive dependence between independent variables.

\section{Feasibility of Using the Factor Analysis}

Before interpreting the results of the factor analysis, the feasibility of using it (fit model) must be tested, which grouped according to the variables used. The feasibility of using factor analysis can be explained as follows:

Table 1. Results of KMO and Bartlett's Test Value

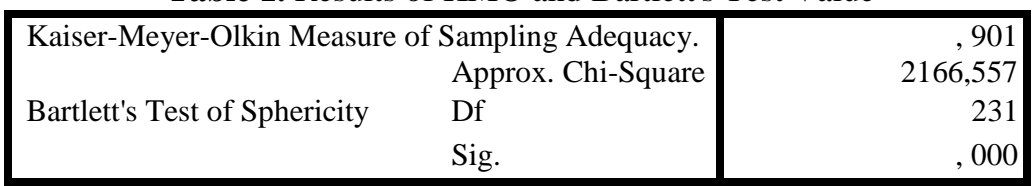

Table 1 shows that the KMO value of the variables used is 0.901. These results indicate that the comprehensive sampling adequacy requirements and the sampling adequacy of each indicator for factor analysis are quite good [11].
Furthermore, from the test results where MSA value is obtained, the value of each factor has met the MSA standard, which is 0.5 , hence can proceed to the next step. The test results can be seen in table 2 .

Table 2. Results of MSA Value for Each Indicator and Communalities

\begin{tabular}{|c|c|c|c|c|c|}
\hline Variable & Indicator & Initial & Extraction & R Table & Information \\
\hline \multirow[t]{2}{*}{ Religious Quality } & $\begin{array}{l}\text { P1 } \\
\text { P2 } \\
\text { P3 } \\
\text { P4 } \\
\text { P5 } \\
\text { P6 }\end{array}$ & $\begin{array}{l}1,000 \\
1,000 \\
1,000 \\
1,000 \\
1,000 \\
1,000\end{array}$ & $\begin{array}{r}, 681 \\
, 744 \\
, 591 \\
, 679 \\
, 334 \\
, 534\end{array}$ & $\begin{array}{l}0.5 \\
0.5 \\
0.5 \\
0.5 \\
0.5 \\
0.5\end{array}$ & $\begin{array}{l}\text { Valid } \\
\text { Valid } \\
\text { Valid } \\
\text { Valid } \\
\text { Valid } \\
\text { Valid }\end{array}$ \\
\hline & P7 & 1,000 &, 798 & 0.5 & Valid \\
\hline \multirow[t]{5}{*}{ Price / Product } & P8 & 1,000 &, 883 & 0.5 & Valid \\
\hline & P9 & 1,000 & , 886 & 0.5 & Valid \\
\hline & P10 & 1,000 &, 863 & 0.5 & Valid \\
\hline & P11 & 1,000 &, 641 & 0.5 & Valid \\
\hline & $\mathrm{P} 12$ & 1,000 &, 775 & 0.5 & Valid \\
\hline \multirow[t]{5}{*}{ Ethics } & P13 & 1,000 &, 666 & 0.5 & Valid \\
\hline & P14 & 1,000 &, 708 & 0.5 & Valid \\
\hline & P15 & 1,000 & , 781 & 0.5 & Valid \\
\hline & P16 & 1,000 & , 698 & 0.5 & Valid \\
\hline & P17 & 1,000 &, 750 & 0.5 & Valid \\
\hline \multirow[t]{5}{*}{ Quality of Service } & P18 & 1,000 &, 842 & 0.5 & Valid \\
\hline & P19 & 1,000 &, 759 & 0.5 & Valid \\
\hline & $\mathrm{P} 20$ & 1,000 &, 824 & 0.5 & Valid \\
\hline & $\mathrm{P} 21$ & 1,000 &, 814 & 0.5 & Valid \\
\hline & P22 & 1,000 & , 793 & 0.5 & Valid \\
\hline
\end{tabular}


Communalities show the effective contribution of each item to the formed factors. In Table 4.8 the value of communalities exceeds 0.5 , this shows that the indicators of the existing variables can be explained by the formed factors. This value indicates that the use of factor analysis is good because it is able to explain most of the original data variants (variance explained).

\section{Factor Analysis Interpretation}

Based on the Eigenvalues score, from 22 indicators in four variables, four main factors are formed because there are four numbers that have Eigenvalues values greater than 1. At the beginning of grouping the indicators, there were several factors that the dominant indicators included in these factors were difficult to be determined because the correlation values of each indicator against the factors were not much different. To overcome this problem, Varimax rotation is carried out so that the correlation of the indicators is only dominant for one factor. Finally, in the results of the data tabulation, there are 4 factors that deserve to be used as forming factors because the minimum value of these factors is 0.5 .

Table 3. Component Matrix Values ${ }^{\text {a }}$

\begin{tabular}{|l|r|r|r|r|}
\hline & \multicolumn{3}{|c|}{ Component } \\
\cline { 2 - 5 } & 1 & 2 & 3 & 4 \\
\hline P1 &, 375 &, 576 &,- 451 &, 077 \\
P2 &, 311 &, 461 &,- 594 &, 286 \\
P4 &, 350 &, 660 &,- 064 &,- 170 \\
P5 &, 410 &, 461 &,- 511 &, 193 \\
P6 &, 291 &, 448 &, 213 &, 049 \\
P7 &, 294 &, 618 &, 167 &,- 193 \\
P8 &,- 814 &,- 003 &, 073 &, 362 \\
P9 &,- 840 &, 050 &, 019 &, 418 \\
P10 &,- 856 &, 053 &, 026 &, 387 \\
P11 &,- 853 &, 027 &, 007 &, 367 \\
P12 &, 755 &, 234 &, 110 &,- 064 \\
P13 &, 695 &, 309 &, 402 &, 186 \\
P14 &, 761 &, 169 &, 221 &, 098 \\
P15 &, 668 &, 098 &, 424 &, 270 \\
P16 &, 762 &, 120 &, 313 &, 298 \\
P17 &, 808 &,- 208 &, 049 &, 006 \\
P18 &, 771 &,- 034 &, 240 &, 313 \\
P19 &,- 850 &, 303 &, 168 &,- 023 \\
P20 &,- 797 &, 327 &, 102 &,- 082 \\
P21 &,- 798 &, 349 &, 217 &,- 133 \\
P22 &,- 759 &, 447 &, 178 &,- 074 \\
\hline Extractiny &,- 667 &, 493 &, 249 &,- 207 \\
\hline
\end{tabular}

Extraction Method: Principal Component Analysis.

a. 4 components extracted.

The results of the rotation of the matrix components above indicate that there are 4 factors that are formed, including:

\section{a) Factor 1}

Factor 1, service quality. It has close and positive correlation with 6 indicators, including: long waiting times in the transaction process at conventional banks, the complexity of obtaining products at conventional banks, delays in conventional bank services, ignorance of conventional bank employees in serving customer needs, low empathy from conventional bank employees toward consumers, and employee disrespectful behaviour while delivering services.

b) Factor 2

Factor 2, price/product. It has close and positive correlation with 4 indicators, including: burdensome administrative costs on conventional banks, monthly fees charged at conventional banks, additional fees for savings services and penalties imposed on conventional banks.

c) Factor 3

Factor 3, ethic. It has close and positive correlation with 6 indicators, including: the existence of agreement on savings costs between consumers and Islamic banks, honest behaviour of Islamic banks, sense of responsibility such as giving zakat, good employee service at Islamic banks, Islamic banks good facilities and good services in selling bank products.

d) Factor 4

Factor 4, spiritual quality. It has close and positive correlation with 4 indicators, including: carrying out fardhu prayers on time, carrying out fardhu prayers in congregation, willingness to share with others, being discreet in every action and bank interest is usury. 
Table 4. Factors, Indicators and Cumulative Percentages

\begin{tabular}{|c|c|c|}
\hline Factor & Indicator & $\begin{array}{c}\text { Cumulative } \\
\text { Percentage }(\%)\end{array}$ \\
\hline Sritual Quality & $\begin{array}{l}\text { carrying out the fardhu prayer on time } \\
\text { carrying out fardhu prayers in congregation } \\
\text { willingness to share with others } \\
\text { being discreet in every action } \\
\text { bank interest is usury }\end{array}$ & $21,532 \%$ \\
\hline Price/Product & $\begin{array}{l}\text { burdensome administrative costs on conventional banks } \\
\text { additional fees for savings services } \\
\text { penalties imposed on conventional banks. }\end{array}$ & $41,299 \%$ \\
\hline Ethical & $\begin{array}{l}\text { the existence of agreement on savings costs between } \\
\text { consumers and Islamic banks } \\
\text {. honest behaviour of Islamic banks } \\
\text { sense of responsibility such as giving zakat } \\
\text { good employee service at Islamic banks } \\
\text { - Islamic bank good services in selling bank products } \\
\text { Islamic banks good facilities }\end{array}$ & $59,955 \%$ \\
\hline Service Quality & $\begin{array}{l}\text { long waiting times in the transaction process at } \\
\text { conventional banks } \\
\text { the complexity of obtaining products at conventional banks } \\
\text { delays in conventional bank services } \\
\text { ignorance of conventional bank employees in serving } \\
\text { customer needs } \\
\text { low empathy from conventional bank employees toward } \\
\text { consumers } \\
\text { Employee disrespectful behaviour while delivering services. }\end{array}$ & $72,929 \%$ \\
\hline
\end{tabular}

\section{DISCUSSION}

The result of factor analysis shows that the factors of ethics and service quality are equally dominant factors in shaping the mindset of consumers switching from conventional banks to Islamic banks. Ethical factors are formed by indicators with a cumulative value of $59.955 \%$. Ethic is one of major factor taken for consideration by consumers. From these factors, there are five indicators that explain the correlation of ethic factors in consumer switching behaviour. Indicators that become the main cause for consumers to switch from conventional banks to Islamic banks are the indicator of the provision of zakat based on obtained profit, the existence of previous agreement for customers and security guarantees. These indicators are the leading advantages of Islamic banks compared to conventional banks which encourage consumers to conduct transactions in Islamic banking.

The factor with the highest cumulative percentages is service quality with $72.929 \%$. There are five indicators that form this factor which explain that the service quality of Islamic banks is able to retain consumers. Optimal services may lead to customers satisfaction which make them loyal to the company. By maintaining the services at optimum rate, the level of consumer movement will be minimized. The characteristics of selling good banking products must come along with excellent service characteristics. With increase in service delivery, it is predicted that customers switching behaviour will be diminished. Therefore, companies that are unable to maintain consumer loyalty will experience enormous losses from customers switching behaviour.

The price / product factor with percentage of $41.299 \%$ is also a factor that influences customers switching behaviour with four indicators. In this case, the cost of charging fees of conventional banks is a factor that triggers customer migration to Islamic banks. While in Islamic bank there is no interest that must be paid by customers and the openness of every banking product transaction that does not burden one party. These are the reasons for customers in switching to Islamic banks.

Meanwhile, the spiritual quality factor with percentage of $21.352 \%$ does not seem to be the dominant factor causing customers to switch to Islamic banks. This could be due to the inadequate socialization in order to provide complete and large information regarding Islamic banking business activities to the wider community. The Muslim community may still consider there is no significant difference between conventional banks and Islamic banks. Therefore, the responsibility of this outreach activity is not only on the shoulders of sharia bankers as the daily operational implementers of the bank, but the responsibility of all parties who claim to be Islam either individually, in groups or institutions which include elements of religious leaders, government, scholars and etc. which have great ability and access in disseminating information to the wider community. 


\section{CONCLUSIONS AND SUGGESTIONS}

Switching Behavior is an activity carried out by consumers due to consumer dissatisfaction with service. Consumer dissatisfaction can arise because of the information process in evaluating brands. Consumers will use past and present information to see which brands are delivering the benefits they expect. This paper examines the switching behavior of Islamic bank customers. Using primary data in the form of a questionnaire with 114 respondents, this research found empirical evidence about the factors that influence the movement of Islamic bank customers using an analytical tool, namely factor analysis. The dominant factors in shaping the mindset and influencing consumers to move from conventional banks to Islamic banks are ethical issues and service quality factors. In addition, price / product and religious quality factors also trigger Costumer Switching.

These findings indicate that banking companies must be able to identify consumer desires in order to maintain and increase consumer loyalty by continuing to maintain the services or services offered. With an increase in service, consumers can feel comfortable in making transactions. In addition, an important point for Islamic banks is an ethical issue. This ethical problem factor, such as the absence of

\section{REFERENCES}

[1] Ajzen, I., The Theory of Planned Behavior. Organizational Behavior and Human Decision Processes, 50, 1991, pp 179-211.

[2] Ahmed, Z., Gull, M., and Rafiq, U., "Factors Affecting Consumer Switching Behavior: Mobile Phone Market in Manchester- United Kingdom". International Journal of Scientific and Research Publications, Volume 5, Issue 7, 2015.

[3] Chau, PYK, PJ Hu., "Examining a Model of Information Technology Acceptance by Individual Professions: An Exploratory Study". Journal of Management Information Systems 18 (4), 2002, pp 191-229.

[4] Chuang, Yi-Fei., And Tai, Yang-Fei. "Research on Customer Switching Behavior in The Service Industry ". Management Research Review Vol. 39 Iss: 8, 2016, pp. $925-939$.

[5] Dharmmesta, BS, "Customer Loyalty: A Conceptual Study as a Guide for Researchers “. Journal of Indonesian Economics and Business Vol 14 No.3, 1998, pp73-88.

[6] Ganesh, J., Arnold, MJ, and Reynolds, KE., "Understanding the Customer Base of Service Providers: An Examination of the Differences between Stayers and Switchers". Journal of Marketing 64 (3), 2000, pp 65-87.

[7] Junaidi. "Public Perception of Choosing and Not Choosing a Sharia Bank (Palopo City Study)“. Journal of Business Focus, Volume 14, No 02, 2015. usury, is an indicator that makes consumers interested in using Islamic banking services. This is because the majority of Indonesia's population, especially the city of Palu, is Muslim. The concept of Islamic banking is directly proportional to the teachings of the Islamic religion that does not apply interest (usury). However, there are still many people who do not understand the difference between profit sharing and interest. Therefore, the bank as a service provider should need to socialize the applied system in order to attract potential consumers in the city of Palu. Ethical problems are problems related to morals, insecurity, unhealthy or behavioral problems related to social norms.

\section{AUTHORS' CONTRIBUTIONS}

All authors contributed equally to this work. All authors commented on the manuscript at all stages. All authors read and approved the final manuscript.

\section{ACKNOWLEDGMENTS}

This work was supported by the Accounting Department, Economic and Business Faculty of Tadulako University.

[8] Keaveney, Susan M. 1995. "Customer Switching Behavior in Service Industries: An Exploratory Study". Journal of Marketing Vol. 159, 1995.

[9] Nelvi, Neneng. "Factors Affecting Customer Decisions in Choosing a Sharia Bank“. Essay., 2015.

[10] Vyas, Vishal., And Raitani, Sonita. "Drivers of Customers' Switching Behavior in Indian Banking Industry “. International Journal of Bank Marketing Vol. 32 Iss: 4, 2014, pp. 321 - 342.

[11] Widarjono, Agus. Multivariate Statistical Analysis First Edition. Publishing and Printing Unit of YKPN Management College, 2010. 